\title{
Evaluation of the antimicrobial and resistance-modulating activities of extracts and fractions of Piper mollicomum (Piperaceae)
}

Ana Raquel Pereira da Silva ${ }^{1}$, Micheline de Azevedo Lima ${ }^{2}$, Jacqueline Cosmo Andrade ${ }^{1}$, Celestina Elba SobralSouza ${ }^{1}$, Maria do Socorro Costa ${ }^{1}$, Maria Audilene de Freitas ${ }^{3} \&$ Henrique Douglas Melo Coutinho ${ }^{1}$

1 Laboratory of Microbiology and Molecular Biology, Regional University of Cariri, Crato-CE, Brazil.

2 Department of Molecular Biology, Federal University of Paraíba, João Pessoa-PB, Brazil.

3 Medical Mycology Laboratory, Federal University of Pernambuco, Recife-PE, Brazil.

Correspondence

H.D.M. Coutinho

E-mail: hdmcoutinho@gmail.com

Received: 31 May 2020

Accepted: 31 July 2020

Published on-line: 14 December 2020

\section{Resumen}

Evaluación de las actividades antimicrobianas y moduladoras de resistencia de extractos $y$ fracciones de Piper mollicomum (Piperaceae)

Este estudio tuvo como objetivo evaluar las actividades antimicrobianas de diferentes extractos de Piper mollicomum Kunth ex Steud. contra cepas estándar y resistentes a múltiples fármacos de bacterias y hongos, así como analizar su potencial para modular la resistencia a los antimicrobianos. Los datos obtenidos en este trabajo demostraron una actividad potenciadora de antibióticos prometedora por parte de P. mollicomum, alentando el desarrollo de nuevas investigaciones para caracterizar las propiedades toxicológicas y farmacológicas de los extractos y compuestos aislados de esta especie, que pueden contribuir al desarrollo de nuevos agentes terapéuticos para combatir la resistencia a los antimicrobianos.

Palabras clave: Actividad antimicrobiana; Resistencia antimicrobiana; Piper mollicomum.

\begin{abstract}
This study aimed to evaluate the antimicrobial activities of different extracts of Piper mollicomum Kunth ex Steud. against standard and multidrug resistant strains of bacteria and fungi, as well as to analyze their potential to modulate antimicrobial resistance. The data obtained in this work demonstrated promising antibiotic-enhancing activity by $P$. mollicomum, encouraging the development of further research to characterize the toxicological and pharmacological properties of the extracts and isolated compounds of this species, which may contribute to the development of new therapeutic agents to combat antibacterial resistance.
\end{abstract}

Key words: Antimicrobial activity; Antimicrobial resistance; Piper mollicomum. 


\section{Introduction}

In a worldwide context, the sustainable medicinal exploration of plant species has represented a promising alternative in the search for new bioactive compounds (Mendes et al. 2011). In particular, the search for new antimicrobial agents has been increasingly urgent as the emergence of resistant microorganisms has been directly correlated with increased mortality rates for infectious diseases. Therefore, antimicrobial resistance is currently a major public health problem worldwide (Pena et al. 2001, Duarte 2006, Coutinho et al. 2008).

In this context, bioprospecting for natural products capable of combating infections caused by resistant bacteria has had a significant impact on antimicrobial drug development. Accordingly, consistent evidence has demonstrated that natural products have immense potential to combat bacterial resistance because, due to their chemical complexity, extracts, fractions and some isolated compounds can impair the development of resistance mechanisms (Daferera et al. 2003, Coutinho et al. 2008).

The family Piperaceae (order Piperales) constitutes one of the most primitive families of angiosperms. Studies have demonstrated that the species in this family have a peculiar metabolism leading to the generation of several secondary metabolites with remarkable biological activities, and as such, have many medicinal applications (Wanke et al. 2007). The genus Piper L. is the largest of this family with more than 1000 species, distributed especially in tropical and subtropical regions of Asia and America (Nunes et al. 2007), among which Piper mollicomum Kunth ex Steud. (popularly known as "Pariparoba", "Jaguarandi", "Jaborandi" and "Jaborandi-Manso") has notable pharmacological potential (Magevski, 2012). Accordingly, studies have demonstrated this species has several biological activities, including antimicrobial (Barbosa et al. 1999, Duarte et al. 2007, Da Silva Alves et al. 2016), larvicidal (Gonche et al. 2005) and antifungal (Lago et al. 2007).

Therefore, this study aimed to evaluate the antimicrobial activities of different extracts and fractions of $P$. mollicomum against standard and multidrug resistant strains of bacterial and fungi, as well as to analyze their potential to mo-dulate antimicrobial resistance.

\section{Materials and methods}

\section{Plant material}

The leaves of $P$. mollicomum were collected in the forest garden of the Federal University of Paraíba (Areia, PB, Brazil), and identified by Prof. Leonardo Félix. After identification, a voucher specimen was registered in the herbarium of the same University (registry code EAN 16120).

\section{Preparation of extracts and fractions from the leaves of Piper mollicomum}

The leaves of $P$. mollicomum were dehydrated in a greenhouse at $40{ }^{\circ} \mathrm{C}$ for $72 \mathrm{~h}$ and then, mechanically crushed. The resulting powder was subjected to 5 cycles of extraction by maceration with ethanol for three days each. The solution obtained was concentrated by evaporation, resulting in the crude ethanolic extract. An aliquot of $190 \mathrm{~g}$ of the crude ethanolic extract was solubilized in $\mathrm{MeOH}$ : $\mathrm{H} 2 \mathrm{O}$ (8:2), and subjected to liquid-liquid partition using chloroform $\left(\mathrm{CHCl}_{3}\right)$ and ethyl acetate (AcOEt) separately. The solutions obtained after this process were treated with anhydrous sodium sulfate $\left(\mathrm{Na}_{2} \mathrm{SO}_{4}\right)$ and subjected to filtration. After these procedures, the solvents were evaporated in a rotary evaporator under reduced pressure (temperature $\leq 50{ }^{\circ} \mathrm{C}$ ), resulting two corresponding phases: Chloroform $(76.11 \mathrm{~g})$ and ethyl acetate (4.22 g).

\section{Preparation of solutions from the extract and fractions of Piper mollicomum}

The solutions used in the tests were prepared as follows: $200 \mathrm{mg}$ of the extract and fractions were dissolved in $1 \mathrm{~mL}$ of dimethyl sulfoxide (DMSO), resulting in solutions with an initial concentration of $200 \mathrm{mg} / \mathrm{mL}$ each. These solutions were diluted (1:20) in sterile distilled water to $10 \mathrm{mg} / \mathrm{mL}$, and prior to the tests, diluted again in sterile water to a concentration of $1024 \mu \mathrm{g} / \mathrm{mL}$.

\section{Microorganisms}

The following microorganisms were throughout this study: standard fungal strains of Candida albicans (C.P. Robin) Berkhout (ATCC 40006), Candida tropicalis (Castellani) Berkhout (ATCC 40042) and Candida krusei (Castellani) Berkhout (ATCC 40147); standard bacterial strains of Staphylococcus aureus Rosenbach (ATCC 25923), Escherichia coli (Migula) Castellani and 
Chalmers (ATCC 10536), Pseudomonas aeruginosa (Schröter) Migula (ATCC 15442), and multiresistant strains of $S$. aureus (SA 358), E. coli (EC 27) and P. aeruginosa (P 03). All strains were provided by the Laboratory of Mycology of the Federal University of Paraiba (UFPB) and maintained in Heart Infusion Agar (HIA, Difco Laboratories Ltda.). Prior to the assays, the microorganisms were cultivated for $24 \mathrm{~h}$ at $37{ }^{\circ} \mathrm{C}$ in brain and heart infusion broth (BHI, Difco Laboratories LTDA).

\section{Drugs}

The following antimicrobial drugs were used in the tests: kanamycin, amikacin, neomycin, gentamicin, amphotericin B, benzoylmethronidazole, mebendazole and nystatin. All of them were purchased from Sigma Chemical Co. (St. Louis, USA).

\section{Determination of Minimim Inhibitory Con- centration (MIC) and analysis of antimicro- bial resistance modulation}

The minimum inhibitory concentration (MIC) was determined using the broth microdilution method. Briefly, an inoculum of $100 \mu \mathrm{L}$ of each lineage was diluted in $10 \%$ Brain Heart Infusion (BHI) broth to a final concentration of $10^{5} \mathrm{CFU} / \mathrm{mL}$ and transferred to the wells of 96-well microdilution plates. Each well was added with $100 \mu \mathrm{L}$ of the solution of the extract or fractions, serially diluted to reach concentrations ranging from 512 to $8 \mu \mathrm{g} /$ $\mathrm{mL}$. The MIC of each extract was defined as the lowest concentrations capable of inhibiting microbial growth. Alternatively, in the antifungal activ- ity analysis, the treatments were added at concentrations ranging from 1024 to $2 \mu \mathrm{g} / \mathrm{mL}$. To analyze the effects of P. mollicomum on the modulation of antimicrobial resistance, the MICs of conventional drugs (section 2.5) were determined in the presence or absence of subinhibitory concentrations $(\mathrm{MIC} \div 8$ ) of the ethanolic extract (EEPM), chloroform fraction (FCPM) or ethyl acetate fraction (FAEPM) of P. mollicomum. After treatments, the plates were incubated for $24 \mathrm{~h}$ at $37^{\circ} \mathrm{C}$ and the readings were performed as previously described (Javadpour et al., 1996). All tests were performed in duplicate and data were expressed as a mean of the replicates.

\section{Results and Discussion}

The ethanolic extract, as well as the chloroform and ethyl acetate fractions of $P$. mollicomum presented MIC values above $\geq 1024 \mu \mathrm{g} / \mathrm{mL}$ against all bacterial and fungal strains evaluated. Similar findings were obtained in the study carried out by Souto (2014), which evaluated the effect of the chloroform fraction and the crude ethanolic extract of P. mollicomum, using the Bioautography method. The authors demonstrated that none of these treatments exhibited clinically effective antimicrobial activity against the strains S. aureus ATCC 25923, P. aeruginosa ATCC 27853, E. coli ATCC 25922 and C. albicans ATCC 76615.

On the other hand, studies using crude extracts of other species belonging to the same genus, including Piper caldense C. DC., Piper cernuum Vell. and Piper lindbergii C. DC., found significant antibacterial activity against Gram-positive

\begin{tabular}{lcc}
\multicolumn{1}{c}{ Bacteria } & Origin & \multicolumn{1}{c}{ Resistance profile } \\
\hline Escherichia coli $\mathbf{2 7}$ & Surgical wound, & $\begin{array}{l}\text { Ast, Ax, Amp, Ami, Amox, Ca, Cfc, Cf, Caz, Cip, Clo, } \\
\text { Im, Can, Szt, Tet, Tob }\end{array}$ \\
Escherichia coli ATCC10536 & - & \\
Staphylococcus aureus 358 & Surgical wound & Oxa, Gen, Tob, Ami, Can, Neo, Para, But, Sis, Net \\
Staphylococcus aureus ATCC25923 & - & - \\
$\begin{array}{l}\text { Pseudomonas aeruginosa ATCC 15442 } \\
\text { Pseudomona aeruginosa 03 }\end{array}$ & - & - \\
\hline
\end{tabular}

Tabla 1. Origen de las cepas bacterianas. Ast: Aztreonan; Ax: Amoxacilina; AMP-ampicilina; Ami: Amikacina; Amox: Amoxilina; Ca: Cefadroxilo; CFC: Cefaclor; Cf: cefaloxina; Caz: Ceftazidima; Cip: Ciprofloxacina; CLO: cloranfenicol; Im: Imipenem; Can: Kanamicina; Szt: Sulfametrim; Tet: tetraciclina; Tob: tobramicina; Oxa: Oxacilina; Gen: gentamicina; Neo: Neomicina; Para: paramomicina; Pero: butirosina; Sis: Sisomicina; Net: Netilmycin; CPM: Cfepime; CTZ: Ceftazidima; Ptz: Piperacilina-Tazobactam; Lev: levofloxacina; Mer: Meropenem; (-) Sin resistencia o resistencia sin relevancia.

Table 1. Origin of bacterial strains. Ast: Aztreonan; Ax: Amoxacillin; AMP-ampicillin; Ami: Amikacin; Amox: Amoxilina; Ca: Cefadroxil; CFC: Cefaclor; Cf: Cephaloxin; Caz: Ceftazidima; Cip: Ciprofloxacin; CLO: chloramphenicol; Im: Imipenem; Can: Kanamycin; Szt: Sulfametrim; Tet: tetracycline; Tob: tobramycin; Oxa: Oxacillin; Gen: gentamicin; Neo: Neomycin; For: Paramomycin; But: Butyrosine; Sis: Sisomycin; Net: Netilmycin; CPM: Cfepime; CTZ: Ceftazidime; Ptz: Piperacillin-Tazobactam; Lev: levofloxacin; Mer: Meropenem; (-) No resistance or resistance without relevance. 
bacteria (Cordova et al. 2010). Moreover, previous research has demonstrated that the leaves of P. mollicomum is rich essential oils, which can potentially concentrate the constituents with antibacterial action. This phenomenon could justify the absence of significant antibacterial activity demonstrated by the extract and fractions evaluated by the present study (Guimarães \& Valente 2001, Bardelli et al. 2008).

The analysis of the antibiotic-enhancing activity demonstrated that $P$. mollicomum has the potential to modulate the activity of antibiotics against resistant bacteria. As shown in table 2, the combination of amikacin the ethyl acetate fraction against $E$. coli reduced the MIC of the antibiotic from 312.5 to $78.12 \mu \mathrm{g} / \mathrm{mL}$, indicating synergism. Synergistic effects were also obtained with the combination of kanamycin with the ethanolic extract and the chloroform fraction, as well as when the ethanolic extract was associated with neomycin against the same strain. In all these combinations, the MIC of the antibiotic was significantly reduced in the presence of the natural product, indicating enhanced antibiotic activity.

With regard to the tests with $S$. aureus, synergistic interactions were obtained from the combination of amikacin with both the chloroform and ethyl acetate fractions, as well as from the combination between neomycin and the chloroform fraction. However, the combination of neomycin with the ethyl acetate fraction caused an antagonistic effect, as observed through an increase in the MIC of the antibiotic (Table 2).

The antibiotic-enhancing effect exhibited by both the extract and fractions of $P$. mollicomum evaluated by this study may have resulted from the action of secondary metabolites such as flavonoids and chalcones, which have been previously identified as antimicrobial compounds in this species (Santos et al. 2015 Almeida et al., 2019).

Finally, the extract and fractions obtained from $P$. mollicomum showed no significant antibioticenhancing effect against $P$. aeruginosa (Table 2), as well as did not affect the activity of antifungal agents against Candida strains (all cases presented MIC values above $\geq 1024 \mu \mathrm{g} / \mathrm{mL}$ against all bacterial and fungal strains evaluated.).

Despite the lack of significant antifungal activity demonstrated in the present research, previous studies have identified the antifungal potential of Piper species. In this context, the essential oil of Piper hispidonervum C.DC. was found to inhibit the growth of phytopathogenic fungi. In addition, different extracts of Piper arboreum Aubl. presented antifungal activity against $C$. krusei, Candida parapsilosis Langeron \& Talice and Cryptococcus neoformans (San Felice) Vuill. strains (Zacaroni 2009, Regasini 2009, Da Silva Alves et al. 2016).

\begin{tabular}{|c|c|c|c|c|c|c|c|c|c|c|c|c|}
\hline \multirow[b]{3}{*}{ Antibiotics } & \multicolumn{4}{|c|}{ EC 27} & \multicolumn{4}{|c|}{ SA 358} & \multicolumn{4}{|c|}{ PA03 } \\
\hline & & MIC in & the pres & nce of & & MIC in & the pres & ence of & & MIC in & he pres & ence of \\
\hline & IVIIC & EEPM & FCPM & FAEPM & IVIIC & EEPM & FCPM & FAEPM & & EEPM & FCPM & FAEPM \\
\hline Kanamycin & 2500 & 312.5 & 312.5 & 1250 & 312.5 & 312.5 & 625 & 312.5 & 1250 & 625 & 625 & 625 \\
\hline Amikacin & 312.5 & 156.25 & 156.25 & 78.12 & 312.5 & 312.5 & 78.12 & 78.12 & 1250 & 625 & 625 & 1250 \\
\hline Neomycin & 1250 & 39.06 & 625 & 156.25 & 625 & 625 & 156.25 & 1250 & 625 & 312.5 & 312.5 & 312.5 \\
\hline Gentamicin & 78.12 & 39.06 & 39.06 & 39.06 & 39.06 & 39.06 & 39.06 & 39.06 & 1250 & 625 & 1250 & 1250 \\
\hline
\end{tabular}

Tabla 2. Valores de las MIC $(\mu \mathrm{g} / \mathrm{mL})$ de los antibióticos en ausencia y presencia del extracto y fracciones obtenidas de Piper mollicomum contra $E$. coli 27, S. aureus 358 y P. aeruginosa 03

Table 4. MIC values $(\mu \mathrm{g} / \mathrm{mL})$ of antibiotic in the presence or absence of the extract and fractions obtained from Piper mollicomum against $E$. coli 27, S. aureus 358 and P. aeruginosa 03 .

\section{Conclusion}

The analysis of the antimicrobial properties of the ethanolic extract and chloroform and ethyl acetate fractions of $P$. mollicomum revealed that these products had no clinically relevant antibacterial and antifungal activities. In addition, they did not enhance the activity of conventional antifungal drugs against Candida strains. However, both the extract and fractions obtained from this plant ex- hibited significant antibiotic-enhancing effects against both Gram-negative and Gram-positive bacterial strains.

In conclusion, the data obtained in this study encourage the development of further research to characterize the toxicological and pharmacological properties of the extracts and isolated compounds of this species, which may contribute to the development of new therapeutic agents to combat antibacterial resistance. 


\section{References}

Almeida KPC, Barros ACV, Pantoja TMA, Cavalcante FSA \& Lima RA. 2019. Prospecção fitoquímica do extrato de Piper mollicomum kunth (Piperaceae) e seu potencial antimicrobiano. Revista Gestão e Sustentabilidade Ambiental (8:3): 550-565. http://dx. doi.org/10.19177/rgsa.v8e32019550-565

Barbosa DA, Passos BO, Braga RS, Benchitrit LC, Santos MIS \& Kaplan M A C. 1999. Atividade antimicrobiana de extratos de Piper mollicomum Kunth (Piperaceae). In: XXI Jornada da Iniciação Científica e XI Jornada de Iniciação Artística e Cultural.

Bardelli KC, Kirizawa M \& De Sousa AVG. 2008. The genus Piper L. (Piperaceae) of microbasin of Sítio Cabuçu-Proguaru Atlantic Rain Forest of Guarulhos, SP, Brasil. Hoehnea (35:4): 553-561. https://doi.org/ 10.1590/S2236-89062008000400007

Cordova SM, Benfatti CS, Magina MDA, Guedes A \& De Cordova CMM. 2010. Análise da atividade antimicrobiana de extratos isolados de plantas nativas da flora brasileira frente a Mycoplasma arginini, M. hominis e Ureaplasma urealyticum. Revista Brasileira de Analise Clinicas (42:4) :241-244.

Coutinho HDM, Falcão-Silva VS \& Gonçalves GF. 2008. Pulmonary bacterial pathogens in cystic fibrosis patients and antibiotic therapy: a tool for the health workers. International Archives of Medicine (1:1): 24. https://doi.org/10.1186/1755-7682-1-24

Da Silva Alves H, Da Rocha V, Raianny W, Costa Fernandes AF, Nunes L E, Pinto D S, . . . Catão RMR. 2016. Atividade antimicrobiana de produtos obtidos de espécies de Piper (Piperaceae). Revista Cubana de Plantas Medicinales (21:2): 168-180.

Daferera DJ, Ziogas BN \& Polissiou MG. 2003. The effectiveness of plant essential oils on the growth of Botrytis cinerea, Fusarium sp. and Clavibacte michiganenesis subsp. michiganenesis. Crop Protection (22:1): 39-44. https://doi.org/10.1016/S02612194(02)00095-9

Duarte MCT. 2006. Atividade antimicrobiana de plantas medicinais e aromáticas utilizadas no Brasil. Revista MultiCiência (7:1): 1-17.

Duarte MCT, Leme EE, Delarmelina C, Soares AA, Figueira GM \& Sartoratto A. 2007. Activity of essential oils from Brazilian medicinal plants on Escherichia coli. Journal of ethnopharmacology (111:2): 197-201. https://doi.org/10.1016/j.jep.2006.11.034

Gonche DDF, Simões M \& Moreira D L. 2005. Produtos Naturais para o Controle da Transmissão da Dengue. Atividade Larvicida de Piper mollicomum Kunth. In: IV Riopharma, Rio de Janeiro.

Guimarães EF, Valente M C. 2001. Piperaceae: Piper. In: Flora llustrada Catarinense (Reitz R, ed.), Itajaí Herbário Barbosa Rodrigues,

Javadpour MM, Juban MM, Lo WCJ, Bishop SM, Alberty JB, Cowell SM, . . McLaughlin ML. 1996. De novo antimicrobial peptides with low mammalian cell tox- icity. Journal of medicinal chemistry (39:16): $3107-$ 3113. https://doi.org/10.1021/jm9509410

Lago JH, Young MCM, Reigada JB, Soares MG, Roesler BP \& Kato MJ. 2007. Antifungal derivatives from Piper mollicomum and P. Ihotzkyanum (Piperaceae). Química Nova 30(5): 1222-1224. https://doi. org/10.1590/S0100-40422007000500032

Magevski GC. 2012. Propagação vegetativa de espécies do gênero Piper e suas potencialidades. Mestrado em Agricultura Tropical. Vila Velha, Brasil: Universidade Federal do Espírito Santo: UFES. MSc. Thesis.

Mendes LPM, Maciel KM, Vieira ABR, Mendonça LCV, Silva RMF, Rolim-Neto PJ \& Vieira J. 2011. Atividade antimicrobiana de extratos etanólicos de Peperomia pelúcida e Portulaca pilosa. Revista de Ciências Farmacêutica Básica e Aplicada 32 (1): 121-125.

Nunes JD, Torres GA, Davide LC, Salgado CC. 2007. Cytogenetics of Piper hispidinervum and Piper aduncum. Pesquisa Agropecuária Brasileira 42 (7): 10491052. http://dx.doi.org/10.1590/S0100-204X200700 $\underline{0700019}$

Penna C, Marino S, Vivot E, Cruañes M C, Muñoz J D, Cruañes J, . . Martino V. 2001. Antimicrobial activity of Argentine plants used in the treatment of infectious diseases. Isolation of active compounds from Sebastiania brasiliensis. Journal of Ethnopharmacology 77: 37-40. https://dx.doi.org/10.1016/s0378-87 41(01)00266-5

Regasini LO, Cotinguiba F, Morandim AA, Kato MJ, Scorzoni L, Mendes-Giannini MJ, ... Furlan M. 2009. Antimicrobial activity of Piper arboreum and Piper tuberculatum (Piperaceae) against opportunistic yeasts. African Journal of Biotechnology 8: 2866-2870. http://dx.doi.org/10.5897/AJB09.182

Santos FP, Alves HDS, Lima EDO, Chaves MCDO. 2015. Flavonoids from Piper glandulosissimum Yuncker (Piperaceae). Química Nova 38 (2): 172-177. https://dx.doi.org/10.5935/0100-4042.20140310

Souto JR. 2014. Avaliação da atividade antimicrobiana de extratos e frações de espécies de piper (Piperaceae) por bioautografia. Campina Grande, Brasil: Universidade Estadual da Paraíba: UEPB. BSc Thesis.

Wanke S, Jamaralino MA, Borsch T, Samain MS, Quandt D, Neinhuis C. 2007. Evolution of Piperalesmatk gene and trnk intron sequence data reveal lineage specific resolution contrast. Molecular Phylogenetics and Evolution 42 (2): 477-497. https://dx. doi.org/10.1016/j.ympev.2006.07.007

Zacaroni LM, Cardoso MG, Souza PE, Pimentel FA, Guimarães LGL, Salgado APSP. 2009. Potencial fungitóxico do óleo essencial de Piper hispidinervum (pimenta longa) sobre os fungos fitopatogênicos $\mathrm{Bi}$ polaris sorokiniana, Fusarium oxysporum e Colletotrichum gloeosporioides. Acta Amazonica 39 (1): 193-198. https://dx.doi.org/10.1590/S0044-59672 0 $\underline{09000100020}$ 